\title{
Saving and Portfolio Allocation Before and After Job Loss*
}

\author{
Christoph Basten ${ }^{\dagger} \quad$ Andreas Fagereng ${ }^{\ddagger} \quad$ Kjetil Telle ${ }^{\S}$
}

July 22, 2015

\begin{abstract}
We investigate the development of household labor income, financial wealth and asset holdings over a nine-year period around job loss, using unique administrative panel data from Norway. Consistent with predictions from theory, the data show additional saving and a shift toward safer assets in the years leading up to unemployment, and depletion of savings after job loss. In the years after job loss the households' after-tax labor income is reduced by about 12,500 USD. Over the same time period households deplete 3,000 USD of their financial assets, of which one third is accumulated prior to the job loss. This suggests that at least some households can foresee and prepare for the upcoming unemployment, which indicates that private savings can to some extent serve as a substitute for publicly provided unemployment insurance.
\end{abstract}

Keywords: unemployment, consumption smoothing, household portfolios, portfolio allocation, optimal unemployment insurance

JEL Codes: D12, E21, E24, G11, J65

\footnotetext{
${ }^{*}$ We are indebted to Luigi Guiso, Andrea Ichino and Erzo Luttmer for helpful guidance, and grateful for helpful comments from the Editor, two anonymous reviewers, Christopher Carroll, John Cochrane, Russell Cooper, Stefano DellaVigna, Sigurd Galaasen, Torbjørn Hægeland, Sturla Løkken, Jørgen Modalsli, Monica Paiella, Kjell Salvanes and Ola Vestad, as well as seminar participants at the 2010 Oxford Clarendon Conference on Labour and Finance, the 2010 Congress of the European Economic Association, the 2012 conference of the European Association of Labour Economists, the 2012 DNB Conference on Household Finances and Behaviour in Times of Crisis, the 2013 Research Symposium at the Federal Reserve Bank of St. Louis, the 2013 Royal Economic Society Annual Conference, the Harvard Labor and Public Economics Brownbag, and the microeconometrics workshops at the European University Institute and Statistics Norway. Financial support from the Norwegian Research Council (\#184563) is gratefully acknowledged. Christoph Basten thanks Statistics Norway for their hospitality during the work on this project. The views expressed in this paper are those of the authors and do not necessarily reflect those of the ETH Zurich, FINMA, or Statistics Norway.

${ }^{\dagger}$ ETH Zurich and FINMA, cc.basten@gmail.com

${ }^{\ddagger}$ Corresponding author: Andreas Fagereng, Statistics Norway, Research Department, Postboks 8131 Dep, NO-0033 Oslo, Norway. Email: andreas.fagereng@ssb.no

§Statistics Norway, kjetil.telle@ssb.no
} 


\section{Introduction}

The financial crisis and the resulting recession have significantly increased the number of unemployed in most OECD economies. Besides drawing on unemployment insurance benefits, a household can smooth consumption during unemployment through depletion of private savings. Private savings enable households to maintain higher consumption during unemployment, and can thus reduce the fall in aggregate demand in recessions. But since households hit by unemployment are typically liquidity constrained, private savings need to be accumulated before job loss to enable consumption smoothing. Anticipation of unemployment can then induce more savings, and if sufficiently many households are affected, result in a demand deficiency that may enforce an economic downturn. Moreover, as the perceived likelihood of unemployment increases, the household will want to store the savings in safer and more liquid assets (like cash or deposits), which can enforce a downturn in financial markets. Thus, empirical analyses of the timing and magnitude of households' responses to upcoming unemployment are important for designing public financial support to workers hit by unemployment, and it might also help us in understanding temporal interdependencies between labor and financial markets.

In this paper we investigate how workers in wealthy welfare states, such as Norway, are able to smooth consumption by foreseeing an upcoming unemployment spell and reacting to it by increasing and reallocating their savings. In particular, we estimate the development of households' labor income, financial wealth and asset holdings through the period from four years before to four years after job displacement. Where previous studies have relied mostly on evidence from the analysis of cross sectional data, we employ a unique panel data registry tracking the same households during the sample period. Hence, we provide new and more reliable evidence on the importance of household private wealth as insurance against unemployment.

The rise in unemployment over the last years have increase government spending on unemployment insurance (UI) benefits. The US spending on out-of-work income maintenance amounted to $1 \%$ of GDP in 2009, a marked increase from $0.24 \%$ in 2005 . The OECD average also amounted to $1 \%$ in 2009 (Adema et al. 2011). With strained public finances and concerns about moral hazard under which UI can prolong unemployment by "subsidizing" it - the question whether insurance mechanisms other than UI benefits can aid consumption smoothing for those hit by unemployment is

an important one. In the optimal UI literature, coined by Baily (1978) and further developed by e.g. Chetty (2006) or Crossley and Low (2011), the main substitute for publicly provided UI is private 
savings. In the extreme case, unprepared "hand-to-mouth consumers" would have to reduce their consumption in line with the unemployment-induced reduction in their income, strengthening the case for publicly provided UI ${ }^{1}$ By contrast, households with sufficient savings might not need these at all to maintain consumption levels. ${ }^{2}$ Indeed, Browning and Crossley (2001) show that households in Canada, particularly those with insufficient prior wealth, have to cut their consumption during unemployment spells when UI benefits are cut. Bloemen and Stancanelli (2005) present similar findings for food consumption in the UK ${ }^{3}$ Finally, results in Card et al. (2007) and Basten et al. (2014) provide further indication of liquidity constraints among unemployed in Austria and Norway.

Despite the theoretical recognition of private wealth as insurance against unemployment, there is limited evidence on the extent to which households are able to accumulate wealth before and decumulate it after job loss, chiefly because of the limited availability of adequate data. Notable exceptions are Engen and Gruber (2001) and Gruber (2001). Engen and Gruber (2001) use the US Survey of Income and Program Participation (SIPP) to test for the presence of precautionary saving, using variations in UI benefit schedules as a source of exogenous variation. Gruber (2001) uses the SIPP to analyze prior holdings and wealth depletion during unemployment. By using the SIPP panels both studies observe household wealth at two points in time, enabling them to take out household fixed effects in their analyses 4

In addition to investigating wealth depletion during unemployment, we investigate the extent of additional saving and of portfolio reallocation in the years leading up to the unemployment spell. This has previously been addressed in a literature on precautionary saving (see e.g. Carroll 2001 and Carroll and Toche 2009, or Guiso and Sodini 2012 for a review), which recognizes that household saving may be motivated not only by the "life-cycle" purpose of smoothing consumption and preparing for retirement, but also by a desire for "precautionary" or "buffer-stock" saving at shorter horizons, to prepare for events such as unemployment (Deaton 1991 and Carroll 1997). Furthermore, some

\footnotetext{
${ }^{1}$ Relatedly, in cross sectional data from the PSID Cochrane (1991) finds that involuntary job losses hamper consumption growth significantly.

${ }^{2}$ Note that the availability of alternative insurance mechanisms captures only the benefit side of the optimal UI framework. To determine whether the current level of UI is optimal, one also needs to know its moral hazard cost, as shown in Chetty (2008). This paper focuses on the benefits of UI; see Røed and Zhang (2003) for a paper addressing the costs for Norway.

${ }^{3}$ This is all the more striking in the light of arguments and findings in Browning and Crossley (2009), whereby households can first, with smaller effects on utility, cut spending on durables, and only thereafter need to cut food expenditures.

${ }^{4}$ In studying the wealth depletion during unemployment, having only two points in time has the disadvantage that the depletion will be underestimated to the extent that some of it takes place before the first or after the second point of observation. While two observations per household do allow to control for household fixed effects in the level of wealth, they do not suffice to control for household trends in wealth over time. In this paper we are able to address these shortcomings through the use of a 13-year annual panel on households' income, wealth and asset holdings - for households experiencing and not experiencing an unemployment spell.
} 
studies investigate the extent to which households' investment in risky assets is affected (negatively) by labor income risk (see e.g. Guiso et al. 1996 using survey data on Italian households, or Betermier et al. 2012 for a study of the portfolios of Swedish job and industry switchers). Further, Palia et al. (2014) investigate the effect of background risk on household portfolio choice using the PSID, and find negative impacts on both stock market participation and the conditional portfolio choice.

The major challenge for such empirical studies is that job loss risk can be endogenous. Households that have chosen riskier jobs may in fact be less risk-averse than others and hence engage in less precautionary saving or be less cautious about holding risky assets, biasing downward any estimates of the effect of unemployment risk on saving or portfolio rebalancing. The precautionary saving literature in particular has tried to address such endogeneity concerns by instrumenting unemployment risk with variables thought to influence this risk, but not to otherwise affect saving (for examples, see Carroll

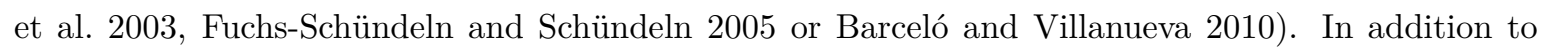
the possible endogeneity of job loss risk or unobservable preferences for work over leisure, there is the problem that households' behavior will necessarily depend not on actual unemployment probabilities (which econometricians can predict with some measurement error and can then instrument), but rather on households' subjective expectations thereof. That is, households can prepare for upcoming unemployment only to the extent that they are actually aware of it. In this paper we focus on cases of actual unemployment and test the hypothesis of no behavioral response against the joint hypothesis that households can to some extent foresee their job loss and are motivated and able to respond to it 5

This paper thus contributes to the literature in four ways. First, we investigate to what extent households prepare for an unemployment spell with additional saving in the years preceding the spell. Second, we examine to what extent they reallocate their savings toward safer and more liquid assets in the same period. Third, we explore whether they draw on prior savings during the unemployment spell. Finally, we address several possible sources of endogeneity by applying individual fixed effects models and by showing that the main results are maintained in the sub-sample of workers who are displaced in association with mass layoffs. Nevertheless, several concerns related to time-varying factors or reverse causality remain, and we discuss them in Sections 3 and 5 We are able to perform the analyses by employing a panel of annual administrative data from Norway in which we observe

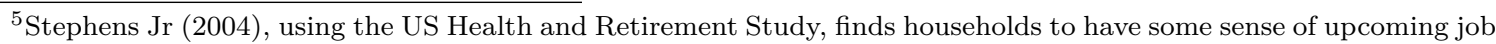
losses and income drops. Guvenen and Smith (2014) use observed economic choices by households (consumption-savings decisions) to assess what households know about their own income process.
} 
labor income, financial wealth, the holdings in different asset classes and debt for each household for 13 consecutive calendar years, 1995-2007. Based on these administrative data, we construct our main sample comprising households where the man experiences his first unemployment spell in one of the years 1999-2003, and complement this with a sample of otherwise comparable households that do not experience an unemployment spell in this period (similar to the approach of e.g. Jacobson et al.|1993

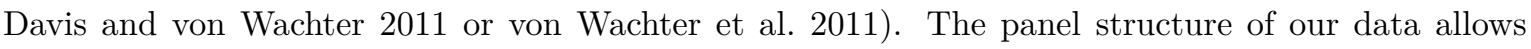
us to control for any unobserved household characteristics that are time-invariant, as well as for any calendar year fixed effects that are household-invariant, such as the effects of being in different phases of the business cycle. We find a modest increase in saving and a more pronounced shift toward safer assets in the years leading up to unemployment, and some depletion of savings after job displacement. To meet the average unemployment-related labor income shortfall of 12,500 USD, households deplete 3,000 USD of their financial assets, of which one third is accumulated prior to the job loss. Within the portfolio of financial assets, prior to job loss, households reduce the exposure to risky assets by 500 USD and increase the holdings of safe assets by 1,500 USD.

Our findings on precautionary saving motives in Norway, an economy with a relatively generous social safety net and low unemployment rates during the period of observation, could indicate that in countries and economies with higher unemployment rates, less generous welfare benefits and more insecurity about future labor market opportunities, the precautionary motives will play an even larger role.

The remainder of this paper is structured as follows. Section 2 presents theory and predictions on how upcoming, current or recent unemployment could affect saving and portfolio choices. Section 3 explains our empirical strategy, Section 4 describes the data, and Section 5 presents the results. Section 6 concludes.

\section{Theoretical Considerations}

Theories relevant to the role of saving and portfolio allocation in response to impending, current and recent unemployment date back many decennia (see e.g. Carroll 2001 or Guiso and Sodini 2012 for reviews). Around and after 1960, a number of formal models surfaced that provided insight on how uncertainty in future income affected consumption and saving behavior (see e.g. Modigliani and Brumberg 1954; Leland 1968, Sandmo 1969, 1970, Dreze and Modigliani 1972). These and later 
contributions established conditions on the intertemporal utility function necessary for precautionary behavior (e.g. Eeckhoudt et al. 1996; Kimball 1990b Kimball and Weil 2009), and recent theoretical contributions have included more complexity by relying on simulation models (Carroll, 2001). Here we draw on this literature in presenting theoretical predictions for structuring our empirical investigations.

We argue that a household will save more in response to a heightened risk of job loss. At least two theoretical arguments support this. First, if the upcoming unemployment spell leads the household to expect a reduction in future income, the household will want to smooth consumption by saving more before the income drop. In life-cycle models where the household can only allocate consumption between the periods by saving (and only one safe asset is available), this result follows from an assumption that consumption is a normal good; see e.g. Sandmo (1968) for one formal treatment. To maintain consumption after job loss, this also implies more depletion of savings during unemployment. Second, however, even if the household does not foresee or expect the upcoming job loss to reduce expected future income, a precautionary motive may still increase saving before job loss. Such precautionary saving is usually described as the extra saving resulting from future income being random rather than determinate (Leland, 1968). This means that a mean-preserving increase in future income dispersion can result in households wanting to save more, for example if their subjective beliefs about the dispersion in future income increases as a pending job loss approaches. Formal analyses of precautionary saving have been provided in two-period models by e.g. Leland (1968) and Sandmo (1970), and has later been extended by several authors, including e.g. Kimball (1990b).

We argue that a household will also rebalance its portfolio from risky and illiquid to safer and liquid assets before a (partly foreseen) job loss. An increase in the mean-preserving dispersion in labor income may affect portfolio choices, and this question is addressed in a growing and more general literature examining how increases in uninsurable background risk affect portfolio choices (e.g. Franke et al. 2011). Our specific question is how a mean-preserving increase in future labor income dispersion affects allocations between safe and risky assets. Elmendorf and Kimball (2000) examine this question in a model where utility is additively separable over time, and they find that if utility exhibits decreasing absolute prudence, an increase in labor income risk (which does lead to more saving) lowers investment in the risky asset. When pressed by an increased risk that the household cannot avoid (the increase in a mean-preserving dispersion of future income), it will try to reduce risks that it can avoid. The household can do so by changing the allocation of the financial portfolio by lowering the share invested in risky and illiquid assets, thus tempering its overall risk 
exposure (Kimball, 1993, 1990a, Elmendorf and Kimball, 2000).

Based on this, to the extent that households foresee and expect an upcoming unemployment spell to reduce future income or to increase the dispersion of future income, we expect to see increasing savings and reallocation from risky to safe assets before job loss. After job loss, we expect to see depletion of savings, and to the extent that income recovers after unemployment, we may expect households to reallocate from safe to risky assets to rebalance the portfolio towards its composition before the job loss.

\section{Empirical Strategy}

Cross-sectional regressions of portfolio changes on employment changes using observational data will typically fail to identify the relationship of interest because households that experience unemployment will differ from those not experiencing unemployment. At the same time, there is the risk of confounding macroeconomic changes in asset markets with developments in individuals' asset holdings related to job loss, since the majority of job losses occur during economic downturns.

Our panel, in which we observe households annually for 13 years, 1995-2007, enables us to trace our outcomes of interest for several years. At the same time we can control for both household fixed effects and calendar year fixed effects. Specifically, our empirical strategy is illustrated by the following model estimated on a panel of households experiencing unemployment:

$$
Y_{i, t}=a_{i}+\gamma_{t}+\sum_{k=-4}^{4} \beta_{k} U_{i, t}^{k}+\delta x_{i, t}+\varepsilon_{i t}
$$

where $Y_{i, t}$ denotes different outcome variables (e.g. financial assets; see Section 4 ) for household $i$ in calendar year $t, a_{i}$ represents the household fixed effects, $\gamma_{t}$ is a vector of calendar year dummies, $U_{i, t}^{k}$ is a vector of dummies for nine relative years $(k)$ around the year of job loss (the relative year zero is the year of job loss) ${ }^{6} x_{i, t}$ is a vector ${ }^{7}$ containing a fourth order polynomial in age and $\varepsilon$ is an

\footnotetext{
${ }^{6}$ The sample is balanced over the 13 calendar years. Hence, we observe all households at least 4 years prior to, and 4 years after job loss, when we require the job loss event to occur between 1999 and 2003. The dataset will contain observations up to 8 years prior to job loss if it happens in 2003, and 8 years after job loss in 1999 . This implies that what relative years are omitted varies for those losing the job in different calendar years, but such differences in levels across calendar years are absorbed by the calendar year dummies. Moreover, the household fixed effects absorb differences in levels across households, and, thus, our estimates of interest, i.e. the development over time, should be robust to what relative years are omitted. In any case, we reran all our main models, and if we included all relative year dummies $(-8$ to +8$)$ and excluded one of the common relative year dummies, or if we excluded all relative year dummies -8 to -4 , our results remained virtually unchanged. With respect to the calendar year dummies we consequently omit the dummy for the year 2004 in all our analysis, the other coefficients are hence to be interpreted relative to this year.

${ }^{7}$ We have also checked that our main results are robust to inclusion of other time-varying controls, like education
} 
error term with mean zero. By taking deviations from the household mean, the household fixed effects swipe out any household characteristic (both observable and unobservable) that does not vary across the observations of each household. Because we employ job losses from different calendar years, we are able to separately identify the calendar year and the relative year fixed effects. For each outcome variable of interest, we can thus estimate this equation and thereby obtain the respective variable's time path (given by the $\beta_{k}$ 's) for relative years before, during and after the year of job loss (see e.g. Jacobson et al. 1993, Couch and Placzek 2010, Davis and von Wachter 2011 or von Wachter et al. 2011).

This empirical strategy identifies the effect of an unemployment event that can be foreseen 8 on saving or portfolio rebalancing - or of an actual unemployment event on subsequent depletion of savings - if the timing of the event is uncorrelated with unobserved determinants of the outcome variable; i.e. we try to estimate how the household would have behaved in the absence of the unemployment event. Although unobservable differences in households that are time-invariant or aggregate calendar year variation, both potential sources of bias in previous studies, do not threaten our identification strategy, several legitimate concerns remain. It is possible, for example, that there exist unobserved "third factors" (confounders) that cause both changes in saving behavior and in the employment situation. Individuals going through some kind of personal crisis might become less disciplined in their saving and investment behavior and might for the same underlying reasons lose their job soon after. If so, effect estimates of the upcoming unemployment would be biased downward 99 By contrast, households that recently managed to put an above-average amount of money on the side might not fear unemployment (given that some individuals have some leeway on when or whether they are laid off), biasing the effect estimate upward. Indeed, we may even imagine that a worker could be saving because he is planning to make himself become unemployed - for example to have more leisure time or to spend time searching for a better job (Rendon 2006) - in which case it is not the anticipation of (involuntary) unemployment that causes saving, but the saving that causes the unemployment.

We attempt to shed some light on the empirical relevance of such endogeneity issues by repeating our analyses for a sub-sample of households whose job loss occurs in association with a major plant

and family size. However, these variables vary very little over time in our sample, and controlling for them thus does not affect the results in any noteworthy way.

${ }^{8}$ Some workers will be aware of the upcoming unemployment spell with certainty, others may only fear it with low probability. At the end of the current section, we elaborate on how this affects the interpretation of our results.

${ }^{9}$ Moreover, where in the life-cycle the worker is, could affect his employment and saving patterns, making it potentially important to control flexibly for age (Jacobson et al. 1993, Bhuller et al. 2011). Hence, we include the fourth order polynomial in age, $x_{i, t}$. 
mass layoff event. As discussed in the literature, mass layoffs from bigger plants are unlikely to be influenced by any individual worker's health or intention to become unemployed. Relying on job loss in association with mass layoffs will not, however, remove selection issues at the plant level (see e.g. Jacobson et al. 1993, von Wachter et al. 2011, Davis and von Wachter 2011, Huttunen et al. 2011 or Rege et al. 2009). Workers selected into plants that undertake mass layoffs, may, for example, be less risk-averse than other workers, they may hold different expectations about future employment opportunities, or their ability to foresee an upcoming unemployment spell may differ. Moreover, firm-level differences in unemployment risks that are not absorbed by the calendar year effects, like regional or industry specific variations in economic conditions, may be correlated with unobserved determinants of saving behavior. Though such correlations could introduce bias, even in the mass layoff sample, we see no obvious reason to believe that concerningly strong correlation of this type exists. In Section 5 we confirm that using the sub-sample of job losers who are separated from their jobs as part of a mass layoff does not significantly change the response patterns of the households. However, in addition to the mentioned caveats, the number of households involved in mass layoff is small, which limits the precision and reliability of this analysis.

More generally, concerns may remain as to whether our results are driven by macroeconomic or life-cycle trends, though such concerns should be adequately handled by the rich and flexible set of control variables, or as to whether the sample selection criteria (age, income, no business income, etc.) or possible mis-coding induce any spurious pattern in the data, though again it seems hard to come up with specific stories for such spurious patterns. One may also argue that the strict requirement of no unemployment in the years prior to the spell selects a sample of "lucky" households, who could engage in higher asset accumulation or behave differently regardless of any upcoming unemployment. To explore this, we repeat our analyses with an interaction of a sample of households subjected to exactly the same criteria as our main sample but who do not experience unemployment in our data window. Instead, they are randomly assigned an artificial year of "job loss". While these households may very well undertake some precautionary saving (in response to general risks or subjective probabilities of job loss), there is no reason to expect any correlation between saving and the artificial job loss, and it it would thus clearly be concerning if we observe such patterns.

Furthermore, it is worth highlighting again that we can expect households to prepare for unemployment only if they can see it coming, which in turn we do not observe. Stephens Jr (2004), using the US Health and Retirement Study, finds that households have some sense of upcoming job losses 
and income drops, but the strength of such expectations depends on the specifics of each national labor market. Thus our tests for behavioral responses to upcoming unemployment spells are essentially investigating the joint hypothesis that households can sense the job loss and that they possess the financial ability to respond to the upcoming event by saving more or reallocating their financial portfolios.

\section{Context and Data}

\subsection{Institutional Context}

The rules protecting individual employees from being laid off are considered strict in Norway (Addison and Teixeira 2003), but a firm may still lay off workers if its demand for labor is permanently reduced. To justify such layoffs the employer has to provide evidence of a real need for cut-backs, a requirement that is typically met if current or expected future competition requires cost cutting. The employer must, however, also justify that the redundant workers cannot be offered any other work within the firm. In association with mass layoffs, there is a long-standing norm protecting the workers with longer tenure. For well-tenured workers the notification notice is to be given at least six months in advance of the layoff, though in the case of mass layoffs the process is more cumbersome and general notice must be given earlier.

Norway is among the OECD countries with the most generous welfare system (see e.g. Kautto 2001), and participation in the welfare programs is compulsory for all residents. The most important services for non-elderly adults include UI, sick money and disability pensions. Though there is a minimum income level necessary to be eligible for UI, it is low by Norwegian standards and in practice employees with a non-minor position throughout a calendar year will meet the requirements. For 2004, for instance, the minimum income level was about NOK 89,000 , or USD $14,000{ }^{10}$ Workers who become unemployed (by at least $50 \%$ ) are entitled to UI of $62.4 \%$ of earnings in the year before job loss, though the replacement rate is lower above a relatively high threshold (amounting to about NOK 380,000 , or USD 60,000 , in 2004). Workers in our sample were typically entitled to UI for two calendar years.

The official retirement age in Norway is 67 , but in practice, early retirement schemes are available

\footnotetext{
${ }^{10} \mathrm{~A}$ worker may also be eligible for UI if he or she over the last three full calendar years has earned twice the minimum income level.
} 
for most workers in Norway from the age of 62 (Vestad, 2013). Some Norwegian households also hold wealth in pension plans, on top of pensions provided by the public schemes. These individual pension plans, however, are payable only at the age of retirement, starting between the ages of 62 and 67 Overall, this institutional setting differs from that of many other countries, possibly also in ways relevant to the external validity of the current analyses. In particular, not only was Norway a generous welfare state, it also had very low unemployment rates during the period of observation. Thus, one should be cautions in extrapolating the precautionary patterns we observe to countries with higher unemployment rates, less generous welfare benefits or more insecurity about future labor market opportunities.

\subsection{Data}

We use administrative data from Norwegian tax registers that cover every Norwegian resident throughout the period 1995-2007. According to Atkinson et al. (1995) the coverage and reliability of Norwegian registry data are considered exceptional and these data enable straightforward merging of information on employment status and labor income with information on household financial wealth (through a unique personal identifier available in all administrative registries in Norway). Observing households in a panel format for a total of 13 years allows us to distinguish household and calendar year fixed effects from what happens in the relative different years around job loss 12

Households are identified as couples who are married or who live together with common children (data to identify unmarried but cohabiting couples without children are not available). We focus on cases of male unemployment, as this will have a more significant impact on the household's financial situation. A household is defined as unemployed in a year if the man receives unemployment benefits. Throughout the analysis, income is defined as the man's pre-tax labor-related income, measured over a calendar year 13

\footnotetext{
${ }^{11}$ Workers in Norway may be part of both a voluntary occupational and voluntary personal retirement savings scheme. The occupational design typically involves the employer contributing $2 \%$ of employee earnings each year, and these are payable from the age of 67 and must be withdrawn over a period of at least ten years. The private ones involve Individual Pension Agreements (IPA) and annuities. In exchange for tax benefits the worker may contribute up to a certain cap, typically 15,000 NOK a year. All contributions made are then payable only from the age of 67 , and over a long range of years. See e.g. OECD (2009) or OECD (2011). In the analysis of household net wealth we include holdings of voluntary personal retirement savings schemes.

${ }^{12}$ In surveys, income and wealth are frequently recalled imperfectly or misreported; see Meyer et al. (2009) for an example of the effects of misreporting in household surveys. For more information on the Norwegian administrative data, see Røed and Raaum (2003), and on the wealth data in particular, see Fagereng et al. (2013).

${ }^{13}$ This includes wage income as well as work-related transfers, such as unemployment benefits, sickness benefits and parental leave benefits. Male income typically dominates household income (see Table 1). Still, we have undertaken some robustness checks using the sum of male and female labor income (instead of only male income), and they confirm
} 
In our main specifications we follow Gruber (2001) in focusing on financial wealth, thus excluding real estate. Chetty and Szeidl (2007) argue that real estate will very rarely be liquidated during unemployment due to the high transaction costs. This is likely even more relevant in Norway than in the US due to special transaction taxes. However, we also construct some alternative measures of household net wealth, i.e. household financial wealth net of debt and a measure of household net wealth including real estate and voluntary personal retirement savings (Carroll et al., 2003, 2011 Mian et al. 2013). Housing wealth is an important life-cycle savings vehicle (also in Norway), and even in the presence of high transaction costs there could be interesting interaction effects between the more short term precautionary demand for saving induced by unemployment risk and the life-cycle motive. Household total debt (inclusive household mortgage, student loans and credit card debt, etc.) is reliably captured in the data. The measure of household net wealth, however, includes real estate wealth measured for tax purposes. In our data tax incentives and regulations implies that the housing values are typically biased downwards. Indeed, infrequent transactions and improvements in the quality of the house make it inherently hard to assess market value of real estate (see e.g. Hwang and Quigley, 2004) and especially over such a long time span. We shall keep these potential sources of serious measurement errors in real estate values in mind when applying this measure. Voluntary personal schemes are payable only at the age of 67 , but the holdings of these are reported every year to the tax authority by the bank or financial institution.

Our measures of wealth are available on the household level at the very end of each calendar year, i.e. we use the sum of the husband's and the wife's assets. This makes sense conceptually as we would expect most of our households to live on a shared budget. Furthermore, the financial variables are more reliably measured at the household level: while the two spouses do report their wealth separately to the tax authorities at the end of every calendar year, they are jointly taxed and they do not have any incentive to ensure that the one who reports holding the wealth is the one who does in fact own it 14 The category of safe assets includes mostly bank deposits, as well as bonds (less prevalent), whereas risky assets are defined to include direct and indirect (mutual fund) holdings of stocks. Some Norwegian households also hold wealth in pension plans, on top of what is provided by the public scheme. These pension plans, however, are payable only at the age of retirement (62 to 67 ), and they are therefore of limited, if any, relevance in our sample of men aged 30-58 at the time of job loss. All

\footnotetext{
the same patterns as those reported in the paper; see also Section 5.3.

${ }^{14}$ Households in Norway are taxed individually when it comes to income taxes, but jointly for the purpose of wealth taxation.
} 
private savings the household performs on top of these accounts, that are not locked until the age of 67 , we observe in our data as part of the financial assets.

Using the above data sources, our main sample is defined as follows. To exclude households still in full-time education or with access to early-retirement schemes, we require the man to be from 30 to 58 (inclusive) years old in the year of job loss 4 We also require that in the year before the job loss the man had sufficient income to be eligible for the publicly provided and universally utilized unemployment benefits. Households with business income, whose unemployment benefits are calculated under different rules, are also excluded. Moreover, we require that households have not experienced any unemployment in the four years leading up to the unemployment spell. To ensure that our comparison of income and wealth across the different relative years is not biased by differences in the sample composition, we require our panel to be fully balanced both across the nine relative years and across the 13 calendar years. We also follow Chetty (2008) in excluding workers who return to the same plant after their unemployment spell, as these are likely to know already at the time of layoff that they will be able to return to their previous plant at a specific time. These requirements leave us with our main analytic sample including the households that were in fact unemployed at some point during 1999-2003. This sample comprises 5,513 households for 13 relative years yielding 71,669 household-year observations. In Section 5.2 we also discuss results from a subset of these households where the job loss occurred in association with a mass layoff.

Table 1 displays summary statistics for this sample of households experiencing unemployment. As we consider men in a relationship (i.e. formally married or cohabiting with the mother of a common child), the mean age of the man is relatively high. About $37 \%$ of the household males have less than high school education. We see that male labor income is more than twice as high as female income, in terms of both the mean and the median. We also note significant dispersions in financial wealth: whereas the mean holdings in the sample amount to more than USD 21,000, the median is about USD 7,000. We also see that the median household does not participate in risky asset markets. Table 2 displays further information on the distribution of the wealth variables. In each of the columns 2 to 6 we display the value of the 10th, $25 \mathrm{th}, 50 \mathrm{th}, 75 \mathrm{th}$ and the 90 th percentile of the given variable separately. We see considerable dispersion in all the wealth variables.

To ensure that our analyses of male labor income and household wealth around job loss are not

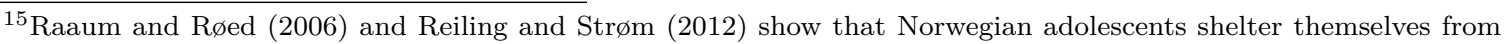
unemployment by undertaking more education during economic downturns. This contributes to the relatively low level of youth unemployment in Norway by OECD standards. In 2007 the youth unemployment rate was $7.3 \%$ in Norway, compared with $10.5 \%$ in the US and $12.0 \%$ in the OECD (OECD 2012).
} 
just driven by outliers in the far right tail of the distribution, we winsorize the variables at the 99th percentile for each year. In the main analyses in Section 5 we use the male labor income and household wealth in levels. As a robustness check we also undertake the analysis with transformed outcome measures. We scale our income and wealth measures by a proxy for permanent income, namely the average of income in the years prior to unemployment (following Engen and Gruber 2001 Carroll et al. 2003), and denote the scaled outcome variable $Y_{P I}$. Next, we follow Carroll et al. (2003) and Dynan (2012) in transforming the scaled outcome variable with the inverse hyperbolic sine function, as suggested in Burbidge et al. (1988) ${ }^{16}$ Opposed to a traditional log transformation, the inverse hyperbolic sine handles both negative values and zeros. Results from analyses applying these transformations to our outcome measures are discussed in Section 5.3.

\section{Results}

\subsection{Main Results}

We now turn to our findings on households' inclination to save and shift assets toward less risky ones before an upcoming unemployment spell, as well as the depletion of savings during unemployment. For our main results, we have estimated the model in Equation (1). Regression results are reported in Table 3, and Figures 1 to 4 plot the predicted paths of labor income, wealth and its components over time, obtained by adding to the estimate of the constant those of the respective relative-year coefficients. Standard errors are clustered at the household level.

We start our discussion with the results for labor-related income, the variable that is directly affected by job loss even without any active responses. From Figure 1 we see that the income path is flat until relative year -1 (recall that the calendar year fixed effects take out average income growth), but then the average household income drops significantly ${ }^{17}$ from about USD 51,000 in the last year before job loss to USD 45,000 in the year of job loss 18 Income then remains low in relative year +1 before it gradually starts increasing again, as more and more households move back into employment.

\footnotetext{
${ }^{16}$ The inverse hyperbolic sine of our scaled outcome measure is given as $g\left(Y_{P I}, \theta\right)=\frac{\ln \left[\theta Y_{P I}+\left(\theta^{2} Y_{P I}^{2}+1\right)^{(1 / 2)}\right]}{\theta}$, where $\theta$ is a dampening parameter. For simplicity we assume $\theta$ to take on a value of 1 , but our results are not sensitive to variations in this assumption. While both the log and the inverse hyperbolic sine transformations make regressions less sensitive to outliers in the far right tail of the distribution, they make regressions more sensitive to households with very low initial holdings for whom small dollar accumulations can show up as substantial relative changes.

${ }^{17}$ We refer to a difference with a p-value of less than 0.05 as statistically significant; see notes in tables for details.

${ }^{18} \mathrm{UI}$ benefits replace $62 \%$ of the previous income at job loss. UI benefits are taxable and therefore included in our income measure, and the income drop from unemployment is hence cushioned by the receipt of UI benefits.
} 
By relative year +4 the difference is reduced to about USD 1,000, which can be partly because of some households still being unemployed and partly because of lower average income in the new job 19 The total income shortfall in this period (relative to the level before unemployment) amounts to about 20,000 USD, equal to about USD 12,500 net of taxes 20

[Figure 1 about here]

Figure 2 reports the estimated time path of financial wealth ${ }^{21}$ We find that the average household starts out with financial wealth of about USD 31,500 at the end of relative year -4 and increases this by more than USD 1,000 by the end of the last calendar year before job loss. This is the average across all households, presumably including both households aware of an impending job loss who respond by saving more, and households not aware of the upcoming job loss who are thus unable to take any measures to save before the job loss. Some households may gradually become aware of the pending job loss several years in advance, like workers in firms that have already started a downsizing process, while others may not anticipate it before receiving the notification notice some (typically six) months in advance. Despite such likely heterogeneity we find pre-unemployment saving that is both statistically and economically significant, suggesting that some households become aware of the upcoming job loss several years in advance and do prepare for it ${ }^{22}$

Moreover, the subsequent wealth depletion of almost USD 3,000 between the end of relative years -1 and 2 is also in line with theoretical predictions. The depletion corresponds to about half of the pre-tax income drop of USD 6,000 in the year after job loss, and a quarter of the accumulated after-tax labor income loss of USD 12,500 in the four years after job loss. This may suggest that the average household can do remaining adjustment along other margins (apart from cutting back on consumption itself), such as spousal labor supply (see Section 5.3 for elaborations on this), temporarily

\footnotetext{
${ }^{19}$ This differs from the findings made for instance by von Wachter et al. (2011), where workers displaced during the 1982 US recession are permanently worse off in terms of income. Presumably, this difference reflects the general strength of the Norwegian labor market with low unemployment rates during the period under consideration.

${ }^{20}$ In the Online Appendix we also split the sample into two groups, one in which the worker finds new work relatively quickly and stay with it, and one group with a prolonged unemployment period. On average, the former group returns to pre-unemployment levels of income within 3 years of job loss, where as the other group remain permanently on a lower level. The workers who find a new job, also deplete a larger portion of their savings during this period. These results are further discussed in Section 5.3.

${ }^{21}$ We have checked that the same pattern prevails if we exclude from the sample the $5 \%$ richest households or the households that participate in the stock and bond markets. Those participating in the stock and bond markets, by contrast, respond more strongly in terms of rebalancing their portfolio structure, as we discuss below.

${ }^{22}$ In Section 1 we noted that the data applied by Engen and Gruber (2001) and Gruber (2001) capture wealth at only two points in time, which has the disadvantage that the depletion will be underestimated to the extent that some of it takes place before the first or after the second point of observation. By a similar argument, applying annual data, as we do, prevents us from analyzing developments that occur and are partly or fully reversed within a calendar year, so our estimates of saving and dissaving are still lower bounds. Moreover, substantial responses occurring only late in the calendar year, possibly tax-motivated, can only be attributed to the overall calendar year in our data.
} 
lower spending on durables (as in Browning and Crossley 2009) or substituting some home production for market consumption. 23

[Figure 2 about here]

To pursue the predictions for portfolio rebalancing, we now turn to Figures 3 and 4 , where we plot the predicted time paths of risky assets (stocks and mutual funds) and safe assets (bonds and cash). The average household significantly shifts wealth from risky assets toward safe assets. In the years leading up to the unemployment, the household accumulates an additional 1,500 USD in safe assets, and reduces its holdings of risky assets by about 500 USD. As the household reaches the year of job loss we also note that it draws on both sources of assets. By the end of relative year 4, the levels of safe and risky assets are back at their levels at the end of relative year -4 . Of course, one should note that the risky assets are held by a smaller share of the households, so the issue of rebalancing does not equally apply to each household in our sample.

[Figures 3 and 4 about here]

[Table 3 about here]

Next, we also consider a common measure of household financial risk taking, the risky share, the fraction of the households' financial portfolio invested in risky assets (stocks or mutual funds). The risky share is either defined on the full sample, or conditional on participating in the asset market (conditional risky share). The left panel of Figure 5 displays both these measures of household financial risk taking. As we see, they largely confirm that households are reducing the exposure to risky assets prior to unemployment (the fraction invested in risky assets is reduced by around one percentage point), that the reduction tends to continue during unemployment, but that the exposure picks up again towards the end of the period. The right panel of Figure 5 displays the patterns from the main analysis done with a median regression (Firpo et al. 2009), which is more robust to outliers, in addition to a regular regression on the risky share, on a sample of households that initially have a positive risky share (in relative year -4). These patterns are generally in line with the main result that the participating households reduce their risky exposure prior to unemployment, and that they

\footnotetext{
${ }^{23}$ We return to changes in spousal labor supply in Section 5.3 We do not have data enabling us to investigate effects in consumption or time use. Moreover, Sullivan (2008) shows that low-asset households in the US increase their levels of unsecured debt in response to temporary unemployment-induced earnings losses. Our data do not include information about types of debt, which disables us from looking at the development of unsecured debt around the time of job loss. We return to the pattern in debt around job loss in Section 5.3
} 
continue to reduce financial risk taking just after job loss. The consecutive build up in risky assets towards the end of the sample window is however somewhat less pronounced ${ }^{24}$ Overall, results are largely in line with the theoretical predictions ${ }^{25}$

[Figure 5 about here]

In Section 3 we discussed how the household fixed effects take out unobserved time-invariant household characteristics, such as the degree of risk-aversion, and how our calendar year fixed effects take out the impacts of, for instance, inflation and the business cycles. Moreover we discussed how controlling flexibly for age is important to handle saving behavior over the life-cycle. Further, we might get an impression of the robustness of our results by checking that they remain when we pool our main sample with a sample of households who never experience unemployment and for whom the year of artificial job loss is randomly assigned ${ }^{26}$ Each of the four sections in Figure 6 show results from one regression including interaction terms for the workers in the sample with artificial job loss. We see that the estimated time paths are flat in our artificial job loss sample, and for the main sample of unemployed the time paths are almost exactly the same as in our main regressions reported above. Finding something else would have been worrying, as households in the artificial job loss sample should not be experiencing any systematic change in the expected probability of unemployment and thus not adjust their portfolio, whereas households with upcoming unemployment spells should - if they foresee the impending job loss - be inclined to increase their financial buffer and adjust the risk profile of the financial portfolio. These findings using the sample of households with an artificial job loss year, but otherwise being selected in the exact same way as our main sample (with criteria when it comes to age, income, no business income) indicate that the sample selection does not create any trends or patterns in the data that would be spuriously captured by the estimated $\beta_{k}$ 's.

[Figure 6 about here]

\footnotetext{
${ }^{24}$ Similarly, Calvet et al. (2009) find evidence on active rebalancing in a shorter panel of Swedish households.

${ }^{25} \mathrm{~A}$ potential concern to our findings is that households tend to invest locally, or simply directly in their company of employment. A decline in the value of risky assets could then coincide with an upcoming job loss simply because the economic region or that particular company performs badly. Unfortunately, we do not observe the number of stocks held at the company level, but we have rerun the analysis on the mutual fund holdings only (where the proportion of shares in any single company is very low), and this replicated our main findings. In addition, we also included local unemployment rates at the regional level in the regressions, and again the results remained unchanged. This may be taken to suggest that omitted variables associated with local economic downturns are not driving our main results.

${ }^{26}$ The union of these two sub-samples constitutes our extended sample of 57,389 households or 746,057 household-year observations.
} 


\subsection{Mass Layoff}

As discussed in Section 3 our estimates are hard to interpret if the workers who become unemployed are affected by a third factor which also affects their financial wealth. We attempt to shed some light on the empirical relevance of such endogeneity issues by repeating our analyses on a sub-sample of households whose job loss occurs in association with a major plant mass layoff event. To identify the subset of households who become unemployed in association with a mass layoff, we count the number of employees and define as mass layoff those cases in which the number of employees decreases by $30 \%$ or more from one calendar year to the next (our results are not significantly different if we instead define mass layoff as a decrease in employment of $50 \%$ ). As this would not have much meaning in the case of two-person plants or in plants that experience significant employment differences between any pair of years, we follow previous studies (see for instance Jacobson et al. 1993 , von Wachter et al. 2011, Davis and von Wachter 2011. Huttunen et al. 2011 or Rege et al. 2009) in imposing some additional requirements. First, we require that plants have employed at least 10 employees in one of the years 1999-2003. We also require that the plant has existed for at least four years and has not already experienced a mass layoff in the above sense in one of the past three years ${ }^{27}$ Finally, because it is rather common for Norwegian firms to move workers from one of its plants to another (Huttunen et al. 2011), we compute this mass layoff rate without counting employees who leave a plant merely to continue working at another plant of the same firm.

[Figures 7-10 about here]

By applying these standard choices from the literature we can extract from our main sample of 5,513 job loss incidences a sub-sample of 1,327 workers who became unemployed in association with a major plant mass layoff, and rerun our main regressions from Table 3 on this sub-sample. The results are presented in Figures $7 \sqrt{10}$ (and Table 4), where the estimates on the mass layoff sample are plotted against the estimates from our main unemployment sample. As we see, the patterns are similar, and if anything indicates e.g. stronger signs of additional savings in financial and safe assets before job loss. Given the strict selection, this sample is small, and hence provides less precise estimates.

\footnotetext{
${ }^{27}$ The degree to which a household can foresee an upcoming unemployment spell will undoubtedly vary substantially across households. This is also true for the sample of job losers in relation to a mass layoff. We have tried to separate those workers hit by unemployment in plants with a recent experience (during the last four years before unemployment) of mass layoff, who may thus assign a higher probability to future job loss, versus those in the more stable plants. We found no statistical difference in the pre-unemployment savings between these two groups, but this may also be due to the very small sample sizes.
} 
[Table 4 about here]

\subsection{Robustness and Sub-samples}

In addition to the main results above, the richness of the data allows us to undertake numerous robustness checks and interesting sub-sample analyses. We report results from some such analyses in this sub-section, and we also include a brief overview of results from additional analyses reported in the Online Appendix.

\section{Alternative Measures of Household Wealth}

As discussed at the end of Section 4 , wealth distributions are likely to be skewed with large outliers potentially affecting results. To ensure that the skewness is not driving our results, and that the results do not hinge on particular operationalizations of our outcome measures, we have rerun the main analyses using both standard log and inverse hyperbolic sine transformations (see Burbidge et al. 1988, Carroll et al. 2003 and Dynan 2012). In Figure 11 we report results for the inverse hyperbolic sine transformation of the outcome variables scaled by a proxy for permanent income (Engen and Gruber, 2001). As we see, the patterns of income and wealth around job loss are largely unchanged, perhaps with a slightly more pronounced peak in the financial wealth and safe asset plot in the year before job loss. When evaluating these patterns at the sample averages for the permanent income proxy and the outcome variables we find that also the magnitudes are comparable to the main specification, however as one would expect the movements in income and assets are somewhat dampened by the transformation. These findings also hold when we instead use the untransformed scaled outcome measures or a standard log transformation of our outcome variables.

[Figure 11 about here]

Our main results are based on measures of financial wealth holdings (and its composition). However, most of the theoretical arguments also apply - although not always as strongly - to measures of debt or other measures of wealth. For example, instead of saving by increasing bank deposits, a household could be saving by increasing repayment of debt; or, instead of consuming out of savings 
during unemployment, a household could try to get a loan. As noted in Section 4 we have (in addition to data on financial wealth) reliable data on household debt. Hence, we construct a first alternative wealth measure, household financial wealth net of debt. We also have data on the tax value of real estate, but as discussed, these data suffer from potentially serious measurement errors. Keeping this caveat in mind, we still use them to construct a measure of household wealth as close as possible to household net wealth. Housing wealth is an important life-cycle savings vehicle (also in Norway), and even in the presence of high transaction costs there could be interesting interaction effects between the more short term precautionary demand from saving induced by unemployment risk and the life-cycle motive. The time pattern of these variables around the year of job loss is depicted in Figure 12. In the top left graph we have plotted the household financial wealth net of debt. To construct it we have subtracted from the household financial wealth the household debt, in order to include as many of the well measured wealth components as possible. Analogous to the financial wealth measure we see that the average household builds up additional savings prior to the job displacement. Next, in the top right graph we have plotted our measure of household net wealth, including now also the housing values with the caution in mind that these are imprecisely measured. Further, the net wealth measure includes the value of holdings of personal retirement savings (see Section 4.1 and Vestad, 2013), that are payable at the age of retirement (67). These results confirm the picture of additional saving prior to job loss, and then depletion during unemployment. Lastly, to supplement the two alternative wealth measures we plot in the lower part of the figure the time path of household debt. The picture shows a reduction in household debt prior to unemployment, with some recovery after job loss. It turns out however, both the reduction and the recovery in the average debt is driven mainly by a very small sample of households who exit the housing market in relation to their job loss (see the Online Appendix, Figure 8) ${ }^{28}$ Overall, these robustness analyses reveal patterns of wealth around unemployment which are largely in line with the results from using the financial wealth measures in the main analysis.

[Figure 12 about here]

\footnotetext{
${ }^{28}$ We have also rerun all our main analyses (Figures 1-4) removing these few households, and the results are virtually unchanged.
} 


\section{Sub-sample Analyses}

Here, we briefly summarize results from a number of interesting sub-sample analyses performed in the same fashion as our main results (applying our workhorse equation (Eq. (1)) on the various sub-samples); details are provided in graphs in the Online Appendix.

We have looked at the sub-samples of home owners and non-home owners separately (status measured four years before unemployment). While the income drop of the two groups seem comparable, the income level is higher for the home owners. The home owners also hold more financial assets, and they build up more financial assets prior to unemployment. These households may be more able to foresee the upcoming unemployment or their higher income may make them more able to save. Moreover, as mentioned in Section 4.1., the UI benefits are capped at income levels above about 60,000 USD (2004), and households with income above this ceiling may thus want to increase their additional saving before job loss to meet their lower UI replacement rate.

We have also split our sample by initial risk taking (holding some risky assets in -4) and rerun our analyses, which reveals that risk taking households have somewhat higher income, and substantially higher financial wealth holdings. They also seem to increase their holdings more before, decrease it during and increase it again after job loss. By definition they have higher initial holdings of risky assets, and they reduce the amounts invested in risky assets significantly prior to job loss.

We have split the sample by household educational attainment, using the completed education of the male and creating three educational categories (low, medium and high). Again, there are clear and expected differences in the income levels, but also higher absolute drops in income for the welleducated at the time of job loss. The high educated also hold considerably higher financial wealth, and their build up and depletion of financial assets prior to and after job loss is also larger in absolute terms than for the other groups. Again, this could be because the high educated are better able to foresee the unemployment; because they are better able to save given their higher income; or because they want to compensate for their lower UI replacement rate by saving more 29

We have looked at results for the sub-samples of households with only male labor income (single earner) and households where both the man and the woman have labor income (dual earner). A dual earner household is defined as one where also the woman had an income above the minimum level

\footnotetext{
${ }^{29}$ We have also split the sample above and below median according to pre-unemployment income, and find similar patterns between the sample of high and low income workers, as between high and low education workers.
} 
required for UI (see Section 4.1) four years prior to the man's job loss. We might expect somewhat smaller responses in dual earner households, as one could imagine these households to be somewhat less dependent on the man's labor income. The income drop of the man is comparable in the two groups, but in line with expectations, both the additional saving and the shifting towards safe assets, are more pronounced in the single earner households than in the dual earner households.

We have split the sample by initial wealth-to-income quartiles, and look at patterns before and after job loss for labor income and safe assets (results for financial assets are similar). As we may expect, the households with higher initial wealth-to-income levels (Q4) see larger absolute drops in labor income at job loss. The wealthier groups (Q3 and Q4) also undertake more saving than the poorer groups (Q1 and Q2) prior to job loss.

Households may respond to a foreseen drop in future income because of the man's unemployment spell by increasing the employment of the woman. We have looked for such an "added worker effect" by studying changes in the woman's labor income around the time of the man's job loss. The female income on average starts going up two years before the male job loss, and reaches a maximum the year after the man's job loss. This could suggest that households on average do anticipate the upcoming job loss, which is again in line with them also starting to save more in those years.

Further, we try to shed some light on differences in workers recovery paths after unemployment. We split the sample into a group of workers that find new work relatively fast, and then remain employed for the duration of the sample window and a group of workers that remain in unemployment for longer time. While being cautious about interpreting the differences due to obvious problems with selection, we note that the former group, return to their previous income levels within 3 years of the job loss, whereas the other group suffers what seem to be a more permanent income shock. The responses in the wealth regressions, also indicate that the workers who do find new work relatively fast seem to deplete more of their savings, than the group that do not. This accords with intuition from theory.

Finally, we consider a different group of job losers, namely households in which the female loses her job. These households are selected using the exact same criteria as for the males in our main analyses. This yields a sample of 4,124 households. The development in income before job loss is similar in this sample of women as in our main sample of men, but while the income drop for men was about 6,000 USD, it is about 2,000 USD for the women. The results are very similar for the build up in safe assets, but less pronounced when it comes to the reallocation of risky assets in the years after unemployment. 


\section{Conclusion}

We have empirically investigated saving patterns and portfolio rebalancing toward safer assets before unemployment, as well as depletion of wealth after job loss. Consistent with the theoretical predictions, we find, first, that the average household does deplete about USD 3,000 of financial wealth in relation to a job loss. More strikingly, almost all of this is made up for by additional saving in the three years before the unemployment spell and in years 3 and 4 after job loss. Furthermore, we also find evidence of portfolio rebalancing in the years before unemployment. The latter two results suggest that the average household is able to foresee the upcoming unemployment spell, and it is then both able and willing to prepare for those rainy days. This shows that in aggregate households' saving may hamper consumption and contribute to demand deficiency if there is fear of widespread future unemployment. Moreover, in countries with high participation in the risky asset markets among workers, uncertainty in the labor market may affect financial markets through this precautionary reallocation mechanism. On the other hand, private savings enable households to maintain higher consumption during unemployment, which may reduce the overall fall in aggregate demand in a recession.

The presence of such saving behavior indicates that at least some workers in our sample are able to foresee and prepare for the upcoming unemployment spell, which indicates that they are partly able to smooth consumption by drawing on their prior savings. While the estimated size of this wealth depletion may be thought to be relatively small compared with the accumulated shortfall in income associated with the job loss, its existence does nonetheless confirm that private savings may serve as a substitute for publicly provided unemployment insurance. We also caution that our findings are based on sample averages, and we show that there is substantial heterogeneity, and thus our main results do not rule out the possibility that some of the poorest households suffer considerably during unemployment or end up with permanently lower wealth afterward. It is also important to bear in mind that the results stem from an economy with very low unemployment rates during the period of observation, and where workers' economic needs are secured by a generous welfare state. In countries with higher unemployment rates, less generous welfare benefits and more insecurity about future labor market opportunities, the precautionary motives might play an even larger role. 


\section{A Figures and Tables}

Figure 1: Labor Income around Unemployment

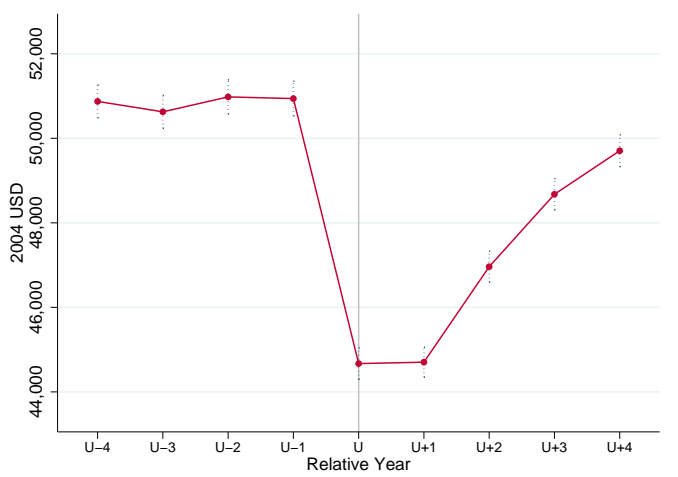

The graph shows the time path of male labor income from four years before to four years after the year of job loss. The estimates (and standard errors behind the 90\% confidence intervals) from estimation of Eq. 11 are reported in Table 3. Standard errors are clustered at the household level

Figure 2: Financial Wealth around Unemployment

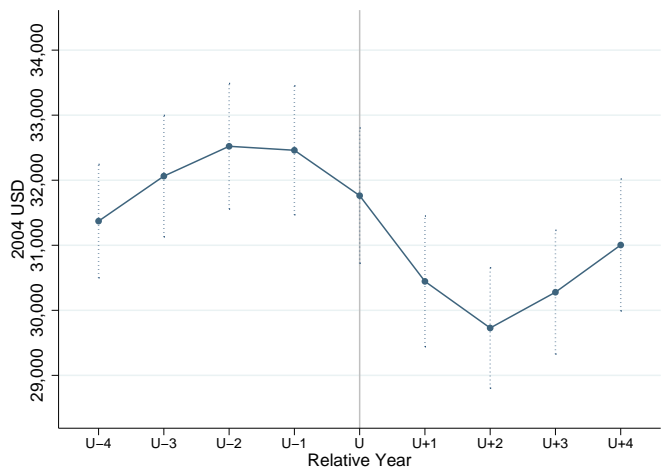

The graph shows the time path of household financial wealth from four years before to four years after the year of job loss. The estimates (and standard errors behind the $90 \%$ confidence intervals) from estimation of Eq. 1) are reported in Table 3. Standard errors are clustered at the household level. 
Figure 3: Safe Assets around Unemployment

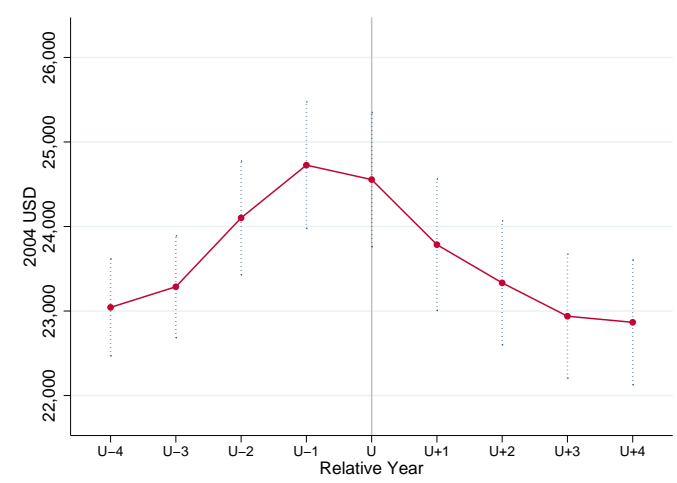

The graph shows the time paths of the households' holdings of safe assets (bonds and deposits) from four years before to four years after the year of job loss. The estimates (and standard errors behind the $90 \%$ confidence intervals) from estimation of Eq. 11 are reported in Table 3. Standard errors are clustered at the household level.

Figure 4: Risky Assets around Unemployment

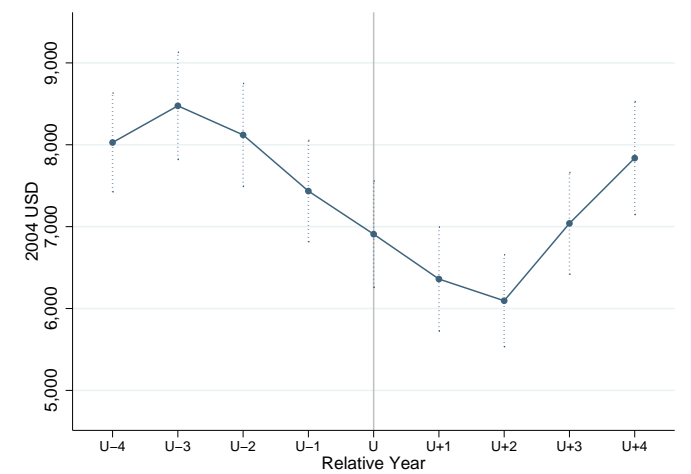

The graph shows the time paths of the households' holdings of risky assets (stocks and mutual funds) from four years before to four years after the year of job loss. The estimates (and standard errors behind the $90 \%$ confidence intervals) from estimation of Eq. (1) are reported in Table 3. Standard errors are clustered at the household level. 
Figure 5: Household Risky Shares

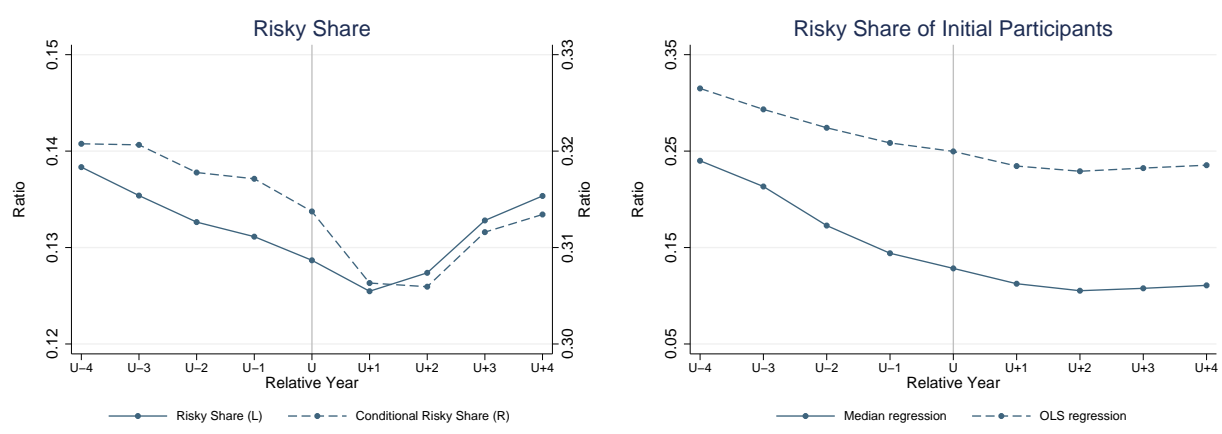

The graphs show the time paths of household risk taking in our main sample from four years before to four years after the year of job loss. The left panel shows the time paths from estimation of Eq. (1) of the household financial risky share (defined as the fraction of household financial wealth invested in risky assets). On the left axis is the outcome measure defined for all households, also those holding no risky assets in their portfolio (the unconditional risky share). On the right axis it is defined only for households with at least some risky assets (Conditional Risky Share). The right panel shows the time paths from the estimation of Eq. (1) with outcome variable the financial risky share using a median and an OLS regression, on a sample of household with positive initial (in relative year -4) financial risky share.

\section{Figure 6: Unemployed vs. Artificial Job Loss Sample}
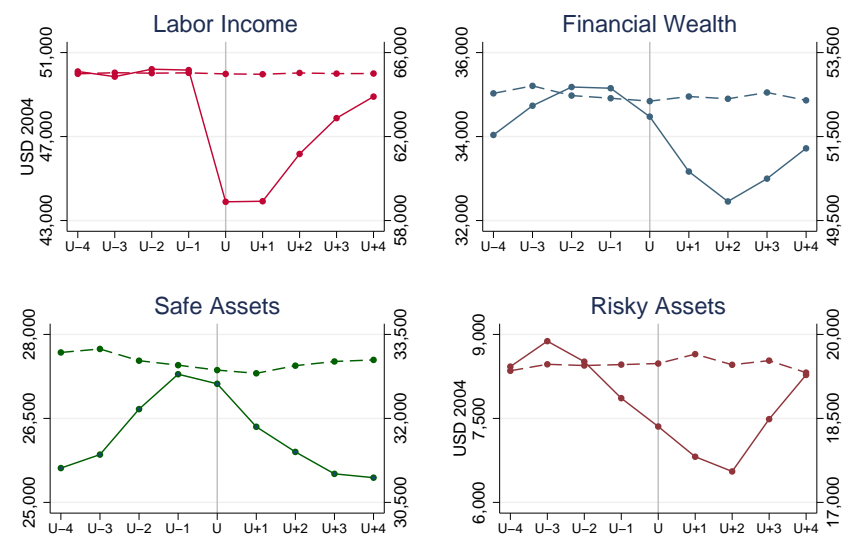

$\longrightarrow$ Unemployed Sample (L)

- - - - Artificial Job Loss Sample (R)

The graphs show the time paths of male labor income, financial wealth, safe assets, and risky assets for households in our main sample and households in the sample where we have assigned artificial job loss randomly from four years before to four years after the year of job loss. The estimates for each outcome variable come from a single regression on the pooled dataset (i.e. Eq. (1) with interactions); see end of Section 5.1 for details. Differences in levels between our main sample and the artificial job loss sample are accounted for by the household fixed effects. 
Figure 7: Labor Income around Unemployment in the Mass Layoff Sub-sample

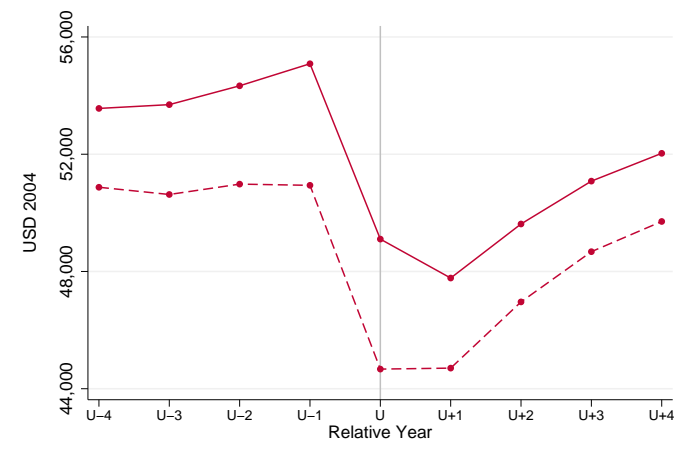

The graph shows the time path of male labor income from four years before to four years after the year of job loss in the Mass Layoff Sample. The estimates from estimation of Eq. 11 are reported in Table 4. For comparison we also include the graph from Figure 1 (Unemployment Sample).

Figure 8: Financial Wealth around Unemployment in the Mass Layoff Sub-sample

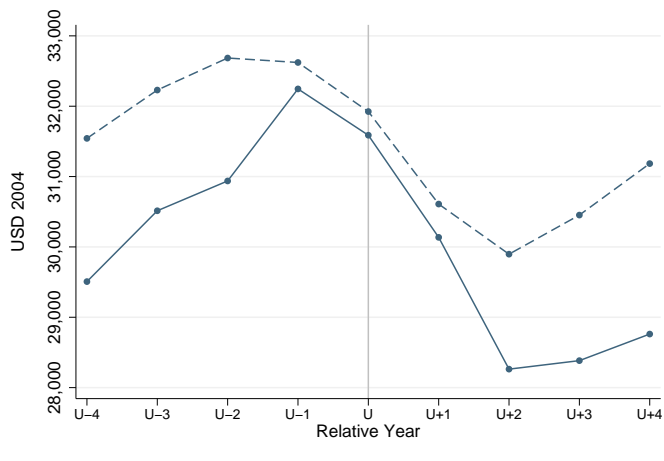

The graph shows the time path of financial wealth from four years before to four years after the year of job loss in the Mass Layoff Sample. The estimates from estimation of Eq. (1) are reported in Table 4. For comparison we also include the graph from Figure 2 (Unemployment Sample).

Figure 9: Safe Assets around Unemployment in the Mass Layoff Sub-sample

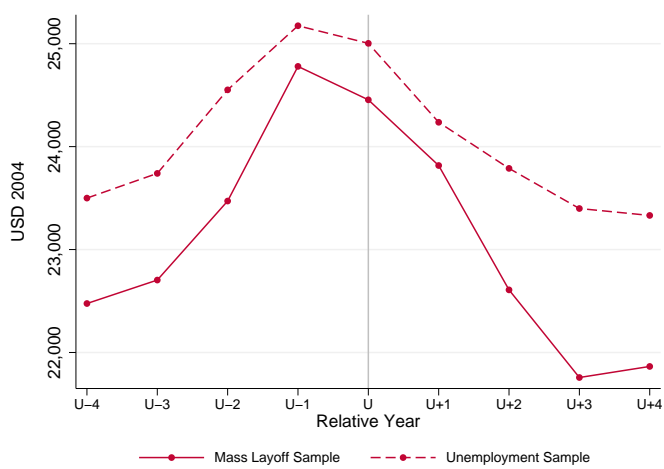

The graph shows the time path of safe assets from four years before to four years after the year of job loss in the Mass Layoff Sample. The estimates from estimation of Eq. (1) are reported in Table 4. For comparison we also include the graph from Figure 3 (Unemployment Sample). 
Figure 10: Risky Assets around Unemployment in the Mass Layoff Sub-sample

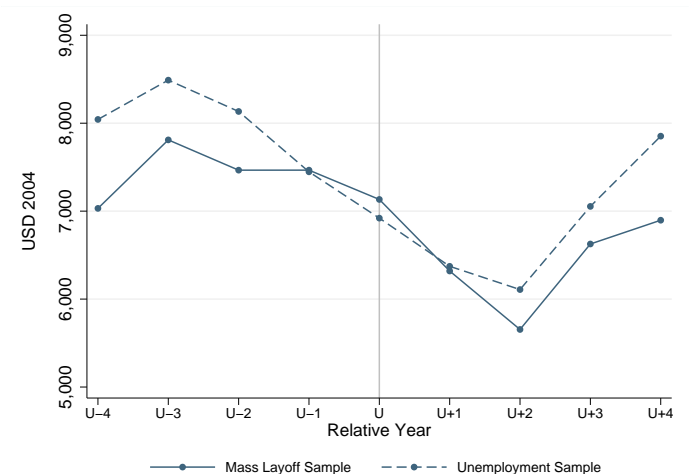

The graph shows the time path of risky assets from four years before to four years after the year of job loss in the Mass Layoff Sample. The estimates from estimation of Eq. 1) are reported in Table 4. For comparison we also include the graph from Figure 4 (Unemployment Sample).

Figure 11: Outcomes Scaled by Permanent Income and Transformed with the Inverse Hyperbolic Sine Function
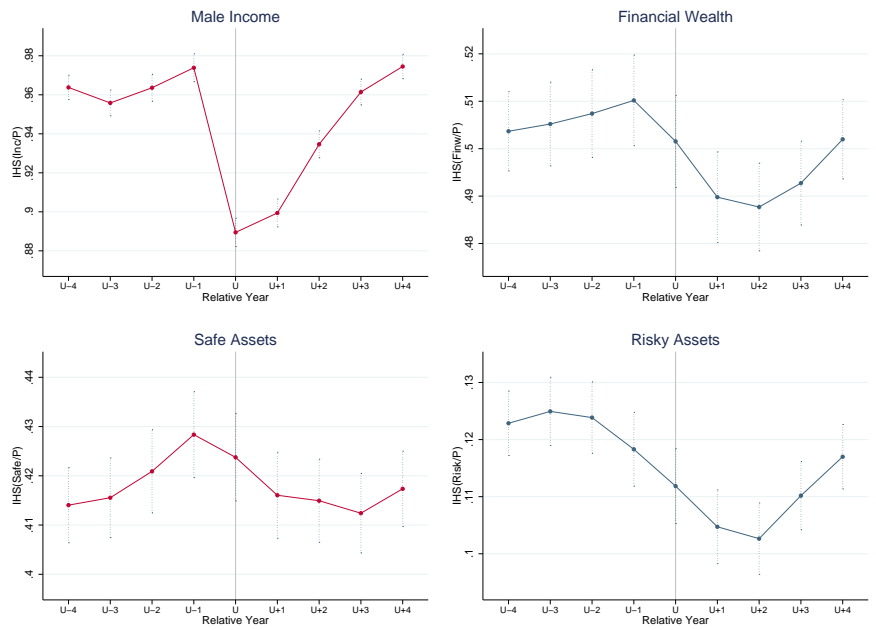

The graph shows the time paths of male labor income, financial wealth, safe assets, and risky assets, all scaled by a proxy for permanent income and transformed using the inverse hyperbolic sine function (see Section 4 for details), from four years before to four years after the year of job loss. The estimates (and standard errors behind the $90 \%$ confidence intervals) are from estimation of Eq. 11. Standard errors are clustered at the household level. 
Figure 12: Alternative Wealth Measures
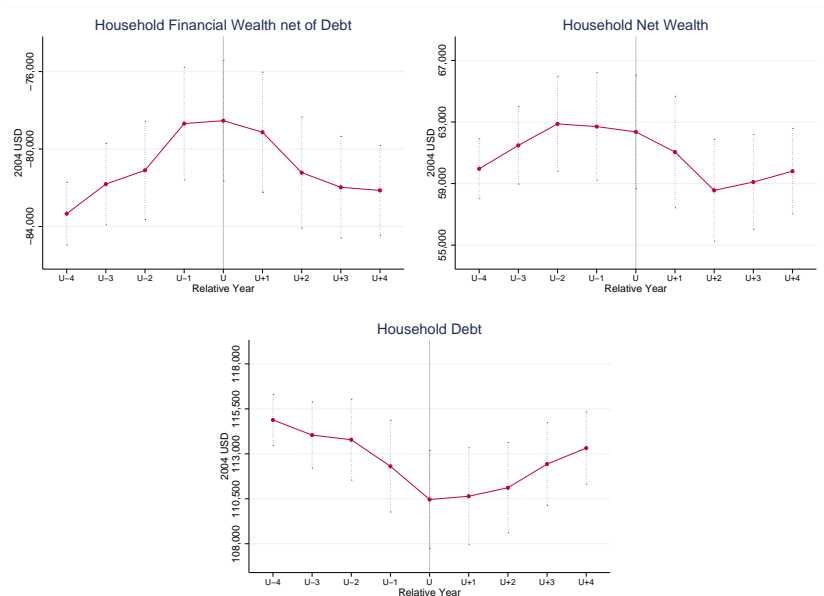

The graph shows the time path of financial wealth net of debt, net wealth and debt from four years before to four years after the year of job loss. The estimates (and standard errors behind the $90 \%$ confidence intervals) are from estimation of Eq. 1 . Standard errors are clustered at the household level. 
Table 1: Summary Statistics Main Sample (pre job loss)

\begin{tabular}{lccc}
\hline \hline & Mean & Std Dev & Median \\
\hline Demographics: & 40.72 & 5.488 & 41 \\
Age Husband & 2001 & 1.464 & 2001 \\
Job loss year & 0.37 & & \\
Share Low Education & 0.39 & & \\
Share High School Education & 0.24 & & \\
Share College Education & & & \\
\hline Labor Income: & 55,196 & 28,762 & 53,325 \\
Male Income & 25,092 & 20,394 & 26,930 \\
Female Income & 80,288 & 39,070 & 81,928 \\
Household Income & & & \\
\hline Asset Holdings: & 21,245 & 43,638 & 6,858 \\
Financial Wealth & 13,820 & 24,103 & 5,556 \\
Safe Assets & 7,424 & 31,469 & 0 \\
Risky Assets & 0.37 & & \\
Share Participation Risky Asset Mkts & 105,252 & 78,867 & 95,144 \\
Household Debt & 68,020 & 133,416 & 59,866 \\
Net Wealth & & & \\
Industry decomposition: & 0.32 & & \\
Manufacturing & 0.09 & & \\
Construction & 0.17 & & \\
Wholesale retail & 0.07 & & \\
Transport / communication & 0.10 & & \\
Real estate. & 0.03 & \\
Education & & & \\
\hline \hline
\end{tabular}

Note: Based on our main sample of 5,513 households. Variables are measured four years prior to the year of job loss, i.e. 1995-1999 since all job losses occure 1999-2003 (cf. Section 4). Where applicable, values are in 2004 USD prices. Minor industry categories are omitted from the table. Shares of educational achievements are calculated with about $1 \%$ of sample missing an observation for this variable.

Table 2: Percentiles of Wealth Variables (pre job loss)

\begin{tabular}{lccccc}
\hline \hline Percentile & Financial Wealth & Safe Assets & Risky Assets & Debt & Net Wealth \\
\hline p10 & 128 & 96 & 0 & 895 & $-85,243$ \\
p25 & 1,690 & 1,4210 & 0 & 40,795 & $-16,104$ \\
p50 & 6,858 & 5,556 & 0 & 95,144 & 59,866 \\
p75 & 21,094 & 15,526 & 1,891 & 148,888 & 151,134 \\
p90 & 51,738 & 35,453 & 13,476 & 200,907 & 228,305 \\
\hline \hline
\end{tabular}

Note: The table displays percentiles separately for each of the wealth measures of the households, based on the main sample for years prior to job loss (cf. Section 4). All values are in 2004 USD prices. 
Table 3: Main Regression Results

\begin{tabular}{lcccc}
\hline \hline & Labor Income & Fin. Wealth & Safe Assets & Risky Assets \\
\hline $\mathrm{U}-4$ & $50,872.7$ & $31,371.1$ & $23,043.2$ & $8,027.9$ \\
& $(235.6)$ & $(531.4)$ & $(350.2)$ & $(367.7)$ \\
$\mathrm{U}-3$ & $50,626.2$ & $32,062.7$ & 23,287 & $8,475.7$ \\
& $(237.3)$ & $(569.0)$ & $(367.5)$ & $(398.8)$ \\
$\mathrm{U}-2$ & $50,979.3$ & $32,521.6$ & $24,101.5$ & $8,120.1$ \\
& $(246.1)$ & $(588.3)$ & $(410.2)$ & $(382.9)$ \\
$\mathrm{U}-1$ & $50,939.5$ & $32,460.4$ & 24,726 & $7,434.4$ \\
& $(249.6)$ & $(604.8)$ & $(456.4)$ & $(376.9)$ \\
$\mathrm{U}$ & $44,669.3$ & $31,762.9$ & $24,554.8$ & $6,908.1$ \\
& $(226.5)$ & $(633.9)$ & $(483.8)$ & $(396.0)$ \\
$\mathrm{U}+1$ & $44,702.9$ & 30,445 & $23,785.1$ & $6,359.9$ \\
& $(215.9)$ & $(612.3)$ & $(474.4)$ & $(387.1)$ \\
$\mathrm{U}+2$ & $46,961.4$ & $29,728.1$ & $23,333.1$ & 6,095 \\
& $(224.3)$ & $(564.7)$ & $(447.1)$ & $(342.2)$ \\
$\mathrm{U}+3$ & $48,675.2$ & $30,278.4$ & $22,938.5$ & $7,039.8$ \\
& $(225.2)$ & $(580.2)$ & $(447.3)$ & $(378.9)$ \\
$\mathrm{U}+4$ & $49,705.5$ & 31,004 & $22,866.3$ & $7,837.7$ \\
& $(229.4)$ & $(618.7)$ & $(450.3)$ & $(420.2)$ \\
\hline Observations: & & & & \\
Unique HHs & 5,513 & 5,513 & 5,513 & 5,513 \\
HHs*Year & 71,669 & 71,669 & 71,669 & 71,669 \\
\hline \hline
\end{tabular}

Note: The table displays the results from estimations of Equation 6 using as outcome variables Male Labor Income, Household Financial Wealth, Household Safe Assets and Household Risky Assets. We report the sum of the constant term and each of the 9 relative year coefficients around unemployment ( $\mathrm{U}$ denotes year of job loss). Household and calendar year fixed effects, as well as a fourth order polynomial in age, are included in all models, but results are not reported. Values are in 2004 USD, and clustered standard errors (at the household level) are reported in parentheses. F-tests for differences between coefficients of different relative years (p-values reported): Labor Income: $\mathrm{p}(\mathrm{U}-1>=\mathrm{U})=0.000, \mathrm{p}(\mathrm{U}<=\mathrm{U}+4)=0.000$, $\mathrm{p}(\mathrm{U}-1>=\mathrm{U}+4)=0.000$. Financial Wealth: $\mathrm{p}(\mathrm{U}-4<=\mathrm{U}-1)=0.051, \mathrm{p}(\mathrm{U}-1>=\mathrm{U}+2)=0.000$, $\mathrm{p}(\mathrm{U}+2<=\mathrm{U}+4)=0.031$. Safe Assets: $\mathrm{p}(\mathrm{U}-3<=\mathrm{U}-1)=0.000, \mathrm{p}(\mathrm{U}-1>=\mathrm{U}+2)=0.000$. Risky Assets: $\mathrm{p}(\mathrm{U}-3>=\mathrm{U}-1)=0.011, \mathrm{p}(\mathrm{U}-1>=\mathrm{U}+2)=0.000$. 
Table 4: Mass Layoff Regression Results

\begin{tabular}{lcccc}
\hline \hline & Labor Income & Fin. Wealth & Safe Assets & Risky Assets \\
\hline $\mathrm{U}-4$ & 53,562 & $28,529.6$ & $22,356.3$ & $6,973.3$ \\
& $(471.8)$ & $(932.9)$ & $(696.5)$ & $(585.7)$ \\
$\mathrm{U}-3$ & $53,691.3$ & $29,551.1$ & $22,600.8$ & $7,750.3$ \\
& $(464.4)$ & $(1,054.4)$ & $(708.0)$ & $(743.9)$ \\
$\mathrm{U}-2$ & $54,334.4$ & $29,987.9$ & $23,383.3$ & $7,404.6$ \\
& $(495.6)$ & $(1,115.8)$ & $(813.6)$ & $(731.3)$ \\
$\mathrm{U}-1$ & $55,085.7$ & $31,307.1$ & $24,703.5$ & $7,403.6$ \\
& $(534.0)$ & $(1,178.8)$ & $(950.1)$ & $(805.3)$ \\
$\mathrm{U}$ & $49,103.7$ & $30,655.6$ & $24,385.8$ & $7,069.8$ \\
& $(471.0)$ & $(1,102.2)$ & $(978.9)$ & $(790.3)$ \\
$\mathrm{U}+1$ & $47,775.6$ & $29,203.8$ & $23,747.3$ & $6,256.5$ \\
& $(446.7)$ & $(1,101.6)$ & $(959.9)$ & $(763.1)$ \\
$\mathrm{U}+2$ & $49,620.2$ & $27,325.2$ & $22,532.2$ & $5,593.1$ \\
& $(445.6)$ & $(1,109.9)$ & $(867.8)$ & $(596.0)$ \\
$\mathrm{U}+3$ & $51,082.2$ & $27,436.8$ & $21,669.9$ & $6,566.9$ \\
& $(431.3)$ & $(1,134.0)$ & $(847.5)$ & $(720.4)$ \\
$\mathrm{U}+4$ & $52,030.8$ & $27,801.9$ & $21,762.9$ & 6,839 \\
& $(449.9)$ & $(1,039.7)$ & $(828.1)$ & $(647.9)$ \\
\hline Observations: & & & & \\
Unique HHs & 1,327 & 1,327 & 1,327 & 1,327 \\
HHs*Year & 17,251 & 17,251 & 17,251 & 17,251 \\
\hline \hline
\end{tabular}

Note: The table displays the results from estimations of Equation 6 using as outcome variables Male Income, Financial Wealth, Safe Assets and Risky Assets on the sample of households separated from their work through a minimum $30 \%$ Mass Layoff. We report the sum of the constant term and each of the 9 relative year coefficients around unemployment (U denotes year of job loss). Household and calendar year fixed effects, as well as a fourth order polynomial in age, are included in all models, but results are not reported. Values are in 2004 USD, and clustered standard errors (at the household level) are reported in parentheses. F-tests for differences between coefficients of different relative years: Labor Income: $\mathrm{p}(\mathrm{U}-1>=\mathrm{U})=0.000, \mathrm{p}(\mathrm{U}<=\mathrm{U}+4)=0.000, \mathrm{p}(\mathrm{U}-1>=\mathrm{U}+4)=0.000$. Financial Wealth: $\mathrm{p}(\mathrm{U}-4<=\mathrm{U}-1)=0.025, \mathrm{p}(\mathrm{U}-1>=\mathrm{U}+2)=0.000, \mathrm{p}(\mathrm{U}+2<=\mathrm{U}+4)=0.231$. Safe Assets: $\mathrm{p}(\mathrm{U}-3<=\mathrm{U}-1)=0.001, \mathrm{p}(\mathrm{U}-1>=\mathrm{U}+2)=0.006$. Risky Assets: $\mathrm{p}(\mathrm{U}-3>=\mathrm{U}-1)=0.645$, $\mathrm{p}(\mathrm{U}-1>=\mathrm{U}+2)=0.003$. 


\section{References}

Addison, J. and P. Teixeira, "The Economics of Employment Protection," Journal of Labor Research, 2003, 24 (1), 85-129.

Adema, W., P. Fron, and M. Ladaique, "Is the European Welfare State Really More Expensive?," OECD Social, Employment and Migration Working Papers, 2011, (124).

Atkinson, A. B., L. Rainwater, and T. M. Smeeding, Income distribution in OECD countries: evidence from the Luxembourg Income Study, Organisation for Economic Co-operation and Development Paris, 1995.

Baily, M. N., "Some aspects of optimal unemployment insurance," Journal of Public Economics, 1978, 10 (3), 379-402.

Barceló, C. and E. Villanueva, The response of household wealth to the risk of losing the job: evidence from differences in firing costs, Documentos de Trabajo, 2010.

Basten, C., A. Fagereng, and K. Telle, "Cash-on-Hand and the duration of job search: Quasiexperimental evidence from Norway," The Economic Journal, 2014, 124 (576).

Betermier, S., T. Jansson, C. A. Parlour, and J. Walden, "Hedging Labor Income Risk," Journal of Financial Economics, 2012, 105 (3), 622-639.

Bhuller, M., M. Mogstad, and K. G. Salvanes, "Life-Cycle Bias and the Returns to Schooling in Current and Lifetime Earnings," IZA Discussion Paper No. 5788, 2011.

Bloemen, H. G. and E. G. F. Stancanelli, "Financial wealth, consumption smoothing and income shocks arising from job loss," Economica, 2005, 72 (287), 431-452.

Browning, M. and T. F. Crossley, "Unemployment insurance benefit levels and consumption changes," Journal of Public Economics, 2001, 80 (1), 1-23.

_ and _. "Shocks, stocks, and socks: Smoothing consumption over a temporary income loss," Journal of the European Economic Association, 2009, 7 (6), 1169-1192.

Burbidge, J. B., L. Magee, and A. L. Robb, "Alternative transformations to handle extreme values of the dependent variable," Journal of the American Statistical Association, 1988, 83 (401), $123-127$.

Calvet, L. E., J. Y. Campbell, and P. Sodini, "Fight or flight? Portfolio rebalancing by individual investors," Quarterly Journal of Economics, 2009, 124 (1), 301-348.

Card, D., R. Chetty, and A. Weber, "Cash-On-Hand and Competing Models of Intertemporal Behavior: New Evidence from the Labor Market," Quarterly Journal of Economics, 2007, 122 (4), 1511-1560.

Carroll, C. D., "Buffer-Stock Saving and the Life Cycle/Permanent Income Hypothesis," Quarterly Journal of Economics, 1997, 112 (1), 1-55.

_ , "A theory of the consumption function, with and without liquidity constraints," Journal of Economic Perspectives, 2001, 15 (3), 23-45.

- and P. Toche, "A tractable model of buffer stock saving," Technical Report, National Bureau of Economic Research 2009.

_ , K. E. Dynan, and S. D. Krane, "Unemployment risk and precautionary wealth: Evidence from households' balance sheets," Review of Economics and Statistics, 2003, 85 (3), 586-604. 
_ , M. Otsuka, and J. Slacalek, "How large are housing and financial wealth effects? A new approach," Journal of Money, Credit and Banking, 2011, 43 (1), 55-79.

Chetty, R., "A general formula for the optimal level of social insurance," Journal of Public Economics, 2006, 90 (10-11), 1879-1901.

_ , "Moral hazard versus liquidity and optimal unemployment insurance," Journal of Political Economy, 2008, 116 (2), 173-234.

- and A. Szeidl, "Consumption Commitments and Risk Preferences," Quarterly Journal of Economics, 2007, 122 (2), 831-877.

Cochrane, J. H, "A simple test of consumption insurance," Journal of Political Economy, 1991, 99 (5), 957-976.

Couch, K. A. and D. W. Placzek, "Earnings losses of displaced workers revisited," The American Economic Review, 2010, 100 (1), 572-589.

Crossley, T. and H. Low, "Borrowing constraints, the cost of precautionary saving and unemployment insurance," International Tax and Public Finance, 2011, 18 (6), 658-687.

Davis, S. J. and T. M. von Wachter, "Recessions and the Cost of Job Loss," Brookings Papers on Economic Activity, 2011, 2.

Deaton, A., "Saving and liquidity constraints," Econometrica, 1991, 59 (5), 1221-1248.

Dreze, Jacques H and Franco Modigliani, "Consumption decisions under uncertainty," Journal of Economic Theory, 1972, 5 (3), 308-335.

Dynan, K., "Is a Household Debt Overhang Holding Back Consumption?," Brookings Papers on Economic Activity, 2012, (Spring), 299-362.

Eeckhoudt, L., C. Gollier, and H. Schlesinger, "Changes in Background Risk and Risk Taking Behavior," Econometrica, 1996, 64 (3), pp. 683-689.

Elmendorf, D. W. and M. S. Kimball, "Taxation of Labor Income and the Demand for Risky Assets," International Economic Review, 2000, 41 (3), 801-832.

Engen, E. M. and J. Gruber, "Unemployment insurance and precautionary saving," Journal of Monetary Economics, 2001, 47 (3), 545-579.

Fagereng, A., C. Gottlieb, and L. Guiso, "Asset Market Participation and Portfolio Choice over the Life-Cycle," Netspar Working Paper, 2013.

Firpo, S., N. M. Fortin, and T. Lemieux, "Unconditional quantile regressions," Econometrica, 2009, 77 (3), 953-973.

Franke, G., H. Schlesinger, and R. C. Stapleton, "Risk taking with additive and multiplicative background risks," Journal of Economic Theory, 2011, 146 (4), 1547 - 1568.

Fuchs-Schündeln, N. and M. Schündeln, "Precautionary savings and Self-Selection: Evidence from the german reunification 'Experiment'," Quarterly Journal of Economics, 2005, 120 (3), 10851120 .

Gruber, J., "The wealth of the unemployed," Industrial and Labor Relations Review, 2001, 55 (1), 79-94.

Guiso, L. and P. Sodini, "Household Finance. An Emerging Field," Handbook of the Economics of Finance, 2012. 
_ , T. Jappelli, and D. Terlizzese, "Income risk, borrowing constraints, and portfolio choice," The American Economic Review, 1996, pp. 158-172.

Guvenen, F. and A. Smith, "Inferring labor income risk and partial insurance from economic choices," Econometrica, 2014, 82 (6), 2085-2129.

Huttunen, K., J. Møen, and K. G. Salvanes, "How destructive is creative destruction? Effects of job loss on job mobility, withdrawal and income," Journal of the European Economic Association, 2011, 9 (5).

Hwang, M. and J. M. Quigley, "Selectivity, Quality Adjustment and Mean Reversion in the Measurement of House Values," The Journal of Real Estate Finance and Economics, 2004, 28 (2-3), 161-178.

Jacobson, L. S., R. J. LaLonde, and D. G. Sullivan, "Earnings losses of displaced workers," The American Economic Review, 1993, 83 (4), 685-709.

Jr, M. Stephens, "Job loss expectations, realizations, and household consumption behavior," Review of Economics and Statistics, 2004, 86 (1), 253-269.

Kautto, M., Nordic welfare states in the European context, Routledge, 2001.

Kimball, M. S., "Precautionary Saving and the Marginal Propensity to Consume," NBER Working Papers 3403, National Bureau of Economic Research, Inc July 1990.

_. , "Precautionary Saving in the Small and in the Large," Econometrica, January 1990, 58 (1), 53-73.

_ , "Standard Risk Aversion," Econometrica, 1993, 61 (3), pp. 589-611.

- and P. Weil, "Precautionary Saving and Consumption Smoothing across Time and Possibilities," Journal of Money, Credit and Banking, 03 2009, 41 (2-3), 245-284.

Leland, H. E., "Saving and Uncertainty: The Precautionary Demand for Saving," Quarterly Journal of Economics, 1968, 82, 465-473.

Meyer, B. D., W. Mok, and J. X. Sullivan, "The Under-Reporting of Transfers in Household Surveys: Its Nature and Consequences," NBER Working Paper, 2009.

Mian, A., K. Rao, and A Rao, "Household Balance Sheets, Consumption, and the Economic Slump," Quarterly Journal of Economics, 2013, 128 (4), 1687-1726.

Modigliani, F. and R. Brumberg, "Utility analysis and the consumption function: An interpretation of cross-section data," in K. K. Kurihara, ed., Post-Keynesian Economics, New Brunswick, H.J.: Rutgers University Press, 1954, pp. 388-436.

OECD, "OECD Private Pensions Outlook 2008," OECD Publishing, 2009.

_ , "Pensions at a Glance 2011: Retirement-Income Systems in OECD and G20 Countries," OECD Publishing, 2011.

_ , "Youth unemployment rate," Employment and Labour Markets: Key Tables from OECD, 2012, (2).

Palia, D., Y. Qi, and Y. Wu, "Heterogeneous background risks, portfolio choice, and asset returns: Evidence from micro-level data," Journal of Money, Credit and Banking, 2014, 46 (8), 1687-1720.

Raaum, O. and K. Røed, "Do Business Cycle Conditions at the Time of Labor Market Entry Affect Future Employment Prospects?," Review of Economics and Statistics, 2006, 88 (2). 
Rege, M., K. Telle, and M. Votruba, "The effect of plant downsizing on disability pension utilization," Journal of the European Economic Association, 2009, 7 (4), 754-785.

Reiling, R. B. and B. Strøm, "Upper secondary school completion and the business cycle," Memo, Dept. of Economics, Norwegian University of Science and Technology, 2012.

Rendon, S., "Job search and asset accumulation under borrowing constraints," International Economic Review, 2006, 47 (1), 233-263.

Røed, K. and O. Raaum, "Administrative registers-Unexplored reservoirs of Scientific Knowledge?," The Economic Journal, 2003, 113 (488), F258-F281.

- and T. Zhang, "Does Unemployment Compensation Affect Unemployment Duration?," The Economic Journal, 2003, 113 (484), 190-206.

Sandmo, A., "Portfolio Choice in a Theory of Saving," The Swedish Journal of Economics, 1968, 70 (2), pp. 106-122.

_ , "Capital Risk, Consumption, and Portfolio Choice," Econometrica, 1969, 37 (4), pp. 586-599.

_ , "The Effect of Uncertainty on Saving Decisions," Review of Economic Studies, 1970, 37 (3), 353-60.

Sullivan, J. X., "Borrowing During Unemployment Unsecured Debt as a Safety Net," Journal of Human Resources, 2008, 43 (2), 383-412.

Vestad, O. L., "Labour supply effects of early retirement provision," Labour Economics, 2013, 25, 98-109.

von Wachter, T. M., J. Song, and J. Manchester, "Long-Term Earnings Losses due to Job Separation During the 1982 Recession: An Analysis Using Longitudinal Administrative Data from 1974 to 2004," Columbia University Department of Economics Discussion Paper Series, 2011. 